Virgin Islands Studies Collective (VISCO)

La Vaughn Belle, Visual Artist, Fellow at the Social Justice Institute at the Barnard Center for Research on Women (BCRW);

Tami Navarro, Associate Director of the Barnard Center for Research on Women (BCRW);

Hadiya Sewer, Visiting Scholar in the Center for the Study of Slavery and Justice at Brown University;

Tiphanie Yanique, author and Professor of creative writing and literature at Emory University.

Contact email belle809@hotmail.com

\title{
Ancestral Queendom
}

\section{- Reflections on the Prison Records of the Rebel Queens of the 1878 Fireburn in St. Croix, USVI (formerly the Danish West Indies)}

\begin{abstract}
This article is written in what can be described as the "post-centennial" era, post 2017, the year marked by the 100th anniversary of the sale and transfer of the Virgin Islands from Denmark to the United States. 2017 marked a shift in the conversation around and between Denmark and its former colonies in the Caribbean, most notably the increasing access of Virgin Islanders to the millions of archival records that remain stored in Denmark as they began to emerge in online databases and temporarily in exhibitions. That year the Virgin Islands Studies Collective, a group of four women (La Vaughn Belle, Tami Navarro, Hadiya Sewer and Tiphanie Yanique) from the Virgin Islands and from various disciplinary backgrounds, also emerged with an intention to center not only the archive, but also archival access and the nuances of archival interpretation and intervention. This collaborative essay, Ancestral Queendom: Reflections on the Prison Records of the Rebel Queens of the 1878 Fireburn in St. Croix, USVI (formerly the Danish West Indies), is a direct engagement with the archives and archival production. Each member responds to one of the prison records of the four women taken to Denmark for their participation in the largest labor revolt in Danish colonial history. Their reflections combine elements of speculation, fiction, black feminitist theory and critique as modes of responding to the gaps and silences in the archive, as well as finding new questions to be asked.
\end{abstract}

Keywords: Fireburn, Black feminism, Virgin Islands Studies Collective, rebellion, Danish West Indies, prison records

\section{Introduction}

In 1917 when the Danish government sold a group of islands in the Caribbean known as the Danish West Indies to the United States, the now named American Virgin Islands began losing its memory (Bastian, 2001). After the 
sale a process of record retrieval began which ultimately splintered the archives placing most in Denmark, some in the United States and an even less sum in the Virgin Islands. As many of the records of the 250 plus years of the Danish colonial period were produced in Danish instead of the English that was most commonly spoken, this has contributed to a compounded lack of access both in language and in distance. The result for Virgin Islanders is a community that has struggled owning its historical memory. Writing about our plight Jeannette Bastian states, "Without recourse to the records, the community can neither counter other interpretations nor consolidate its own; without ownership of its history, it continues to be history's victim" (Bastian, 2003, p. 48). This article is part of our continuing effort at possession.

The 1878 Fireburn is one of the foremost events in our cultural memory. It produced our most beloved heroines, Queen Mary being the most popular, with folk songs, a highway, and a monument in her honor. However, beyond the legend there is not much known about the event, the social, political or economic circumstances leading up to it or the people who participated in what can be said to be the largest labor rebellion in Danish colonial history. The prison records of the four women who were ultimately charged and sentenced to death, then with this sentence commuted sent to be imprisoned in Denmark, has been largely hidden in the historical archive only to emerge during the 2017 centennial anniversary of the transfer in an exhibition at the Workers Museum in Copenhagen. For the few Virgin Islanders who were able to see the exhibit this was a profound moment, a moment where collective memory and historical record collided, challenging both and sparking new questions.

This article is motivated by the need to continue to explore not only the archive, but also archival access and the nuances of archival interpretation and intervention. This text aims to extend our interventions beyond national boundaries in order to complicate engagement with the archives, but also to disseminate the knowledge to and share in conversation with a wider group of interlocutors: actual, potential and imagined.

The four co-authors of this article are (in alphabetical order) La Vaughn Belle, Dr. Tami Navarro, Dr. Hadiya Sewer and Prof. Tiphanie Yanique. Together, we make up the founding body of the Virgin Islands Studies Collective (VISCO). We are a group of academics, artists, and activists who are committed to centering the Virgin Islands as a site of inquiry and theorization. We are centrally concerned with the erasure of the Virgin Islands from larger discourses - the Danish colonial archive and the Danish cultural memory being key sites of erasure. As a collective, VISCO is committed to a practice of collaboration-this article being one such example.

In doing this, we present our article in four parts (excluding this introduction). Each of the four writers uses her own intellectual training and creative practice to make her intervention. As a result, this article moves tonally from scholarly to memoiristic - while also being informed by our collective conversations and contexts. As a methodology collectivity has been central to our work, understanding that our various disciplines provide unique ways of producing knowledge and that together we can challenge and inform one another in new ways. We combine speculation, fiction, anthropology, philosophy and black feminist theory as modalities central to this effort, albeit we employ them with different degrees in our own individual reflections. However, central to each of our interventions is the idea of embodied knowledge and we position our own lived experience as Virgin Islanders in the archival engagement. In doing so we can take up the space that the gaps in the archives have left us to contend with.

In Dr. Navarro's "Through a Glass Darkly: Retracing Black Life in the Danish West Indies" she examines the connection between two young women (herself and Queen Agnes) via lived experience but also seemingly by happenstance - a kind of magic made possible by the facts of both young women being raised in the same place, with similar cultural expectations and determination. Understood in Dr. Navarro's essay is the idea that the happenstance may not be a mistake, but may rather be made possible by spiritual intervention, or made most palatable by gaps in the archives through which a social scientist may fit herself. In this regard, Dr. Navarro takes a historical and anthropological approach in her essay. 
Dr. Sewer's essay, "I Too Am the Rebel Queen Mary" responds to the penal record of Queen Mary Thomas. This essay uses Virgin Islands oral tradition, particularly song celebrating Queen Mary, as a source of communal remembering and learning. She notes that Virgin Islands self-awareness is tied to awareness of the Queens of the Fireburn. She posits that this knowing is one informed by blackness, femaleness, activism, and working class identities, thus suggesting that potential liminal identities are actually centered in VI identity. "I Too Am the Rebel Queen Mary" is written with an ethnographic and philosophical approach, but also makes clear that knowledge, power and the arrival of both on the self is situated both inside and outside of the academy.

In "Enslaved to Enthroned" novelist and poet, Prof. Tiphanie Yanique, uses imagination to read into the archives what is unclear, suggested or entirely absent. In doing this Prof. Yanique works within the magical realism tradition, used by colonized writers notably from the Caribbean, Latin America, and Africa, to make possible what otherwise may seem impossible. Yanique uses her own lived experience to imagine a political and social kinship between herself and Queen Mathilde, in order to ask what makes a queen, what is queenliness, and what is particular to queendom in the Virgin Islands.

La Vaughn Belle, visual artist, approaches the archives as opportunities towards limitless renewals of knowing. In her article, "A Queen by Another Name: Susanna Abrahamson aka Bottom Belly, Or..." she first presents the reader with multiple titles, which suggest the meta-textual knowing made possible by Belle's own Virgin Islands identity, her gender, her blackness and her own queenliness. Notably, however, Belle clarifies that this multiplicity also comes from a scarcity of concrete knowledge, which requires a continuous questioning and requestioning of the archives.

A hallmark of each essay is the realization that we know very little. The archives are often spare, contradictory or suspiciously repetitive. As we looked at these archives we were forced to ask rather simple questions, such as who wrote these archival notes? Where were they written? The Danes are known for meticulous recordkeeping, but would they have applied that same care to recording the lives and experiences of colonized persons? What do we, as women, knowledge producers, and mothers from the Virgin Islands, see in the archives or in the archival absences, that may not have been seen before--due to the gendered, racial and national positionality of previous students and scholars?

We understand that our positionality as four black women from the Virgin Islands puts us in a serendipitous position with which to engage with four black women from the Danish West Indies known as the Queens of the Fireburn. We also recognize that our work would not be possible without the work of numerous other scholars, artists and activists who wrote and created before us. To do this work of engaging with the archives of these four queens in a political, personal and intellectual way, we four, relied heavily on scholars who have studied these, and related archives, and who have made engagement with Virgin Islands history and culture their life's work. We must thank Arnold Highfield and George Tyson for their vital in-person and telephonic communication with us. We also acknowledge our necessary engagement with the work of multiple scholars and archivists: Temi Odumosu, Sylvia Wynter, M. Cynthia Oliver, Mathias Danbolt, Mette Kia Krabbe Meyer, Elizabeth Rezende, Wayne James, Jeannette Bastian and Michel-Rolph Trouillot. We also thank Heidi Bojsen for her critical work in providing us partial English translations of these prison records from the original Gothic Danish. There are many codices in the documents that refer to specific penal texts that are still in the process of being translated or researched. Finally, we also acknowledge that our ability to engage with these persons, archives and secondary materials (via air travel, via the internet, via group video chats and phone calls) clarifies a great privilege that is dependent not only on the fact that we all have degrees which enable us to use institutional funds and technology, but also the happenstance of the time (2019) and place (the United States and its territory, the USVI) where movement and communication across space is possible in ways it has never been before. We note that four black women, all mothers with small children, doing this work together may have been somewhat impossible for past generations-we appreciate that we are the imagined of our mentors and elders. 


\section{Through a Glass Darkly: Retracing Black Life in the Danish West Indies By Tami Navarro}

There is something to be said for serendipity. In May of 2019, I was scheduled to participate in a symposium at the University of Copenhagen entitled "Archival Encounters: Colonial Archives, Care and Social Justice." This symposium presented me with an ideal opportunity to introduce the work that my colleagues and I had been doing through our Virgin Islands Studies Collective (VISCO), and marked a moment in which I could engage with the penal records of the Queens of the Fireburn. At the time of this symposium, Heidi Bojsen, who had generously and diligently been working to translate these records into English, had only been able to work with one set of prison records, given the difficulties posed by the flourishes of colonial-era handwriting and outmoded turns of phrase. The record that had been completed was that of Queen Agnes, and I used this record in my lecture as a case study of the history we, as VISCO, are pushing against: The quantitative assessment of colonial subjects found in this prison record is in direct opposition to the more fully-human rendering we hope for-and seek to provide-through our work in the Virgin Islands. On the point of serendipity: As fate would have it, I was randomly assigned a 'queen' to engage with for this article several weeks after the symposium. It was, of course, the Virgin Islands woman whose life I had already begun thinking and writing about, Queen Agnes.

The prison record of Axeline Solomon (also known as Agnes) lists, as her property brought into incarceration, a single pair of earrings. In fact, all four (4) of the queens bring with them a pair of earrings (Mary, the leader of the group, also brings with her a ring). This banal, seemingly everyday, item of adornment-a pair of earringsbecomes significant in context: They each brought this jewelry with them to Denmark where they knew they were to be tried for crimes ranging from arson to murder. For these crimes, they were sentenced to death (sentences that were eventually commuted to hard labor). What did it mean that they each chose to bring an item of adornment, of beauty, with them on this journey that they knew could well end in their death? Why would they bring something so seemingly-frivolous? Perhaps a pair of earrings is all Agnes had in the way of material possessions, and she felt the need to have them with her. Perhaps she had no one she could give them to or entrust to keep them for her-although as the mother of three children, this explanation is unlikely. Perhaps, then, the explanation is a bit further afield, harder to pin down and certainly outside the domain of colonial archives. It may well be that these earrings made the journey from St. Croix to Copenhagen because they made their owner feel beautiful, or powerful, or both.

Like many girls born in the Virgin Islands, I had my ears pierced before I turned one year old: I have seen photos of myself as an infant, golden studs reflecting the glare of the sun. These earrings I have seen, but do not recall. The earrings I remember, the ones I can see clearly in my mind, are a small pair of braided gold hoops. My mother bought them for me from a store in Christiansted that was having a going out of business sale-even then, in the 1980s, gold was a luxury, although not yet as prohibitively expensive as it would become in later years. At any rate, the store was named Ay Ay Gold ("ay ay" after an indigenous, pre-Columbian, name for St. Croix) and stood just a few feet away from Fort Christiansvaern where unruly Africans (slaves and, later, colonial subjects) were whipped and jailed by Danish officials. I knew nothing of this history, nothing of this proximity to torture, punishment, and capture on the afternoon we purchased those earrings. Standing on the harbor and wearing my new earrings I knew only that I felt different, set apart somehow. Was it because the earrings had been expensive? I can't say, but I do know that this bit of adornment made me feel more comfortable taking up space, being seen.

I have entitled this essay "Through a Glass Darkly: Retracing Black Life in the Danish West Indies." This phrasing comes from the Apostle Paul in his letters to the Church in Corinth, where he writes, "For now we see through a glass, darkly; but then face to face: now I know in part; but then shall I know even as also I am known" (1 Corinthians Chapter 13 verse 12). It is this project, of being known, that I take up in the remainder of this essay. For Black residents of the Danish West Indies, the islands that have been known as the United States Virgin 
Islands since their sale and purchase by that country in 1917, this project has been a long and imperfect one. These subjects have often been included in colonial archives, but as backdrops or props that would serve to demonstrate wealth. In these images, Black subjects were seen, partially, but not known. The racist tropes that were the context for Black visibility in the records of the Danish West Indies precluded either any sense of interiority or dialogue (Image $1^{i}$ ). In what follows, I present competing representations of Black life in the formerDanish West Indies--one archival source which attempts to quantify the life and actions of a Queen of the Fireburn and another which attempts a more capacious remembrance of this Fireburn and its leaders. While neither of these detail fully the lives of these subjects, this exercise points the way-I argue-toward seeing Black life in these islands more clearly.

Denmark's colonial presence in the Caribbean extended from 1733 with the purchase of the islands of St. Thomas, St. John, and St. Croix through their sale to the United States in 1917. During much of this time, as throughout the region, a system of plantation agriculture by enslaved laborers who were primarily cultivating and processing sugarcane was the cornerstone of these islands' wealth. It was not until 1848 that the system of slavery ended in the Danish West Indies. Although, it is of note that while Denmark announced the decision to end their participation in the slave market earlier, in 1792, they allowed what they termed a 10-year 'grace period'-a decade during which the slave population increased upward through what historian Neville Hall has described as "feverish importations" (Hall, 1992, p.3). On July 3, 1848 this unsustainable situation erupted in the form of a major slave rebellion on St. Croix, led by an enslaved worker named Moses Gottlieb-better known locally as General Buddhoe. Frustrated with having the date of their emancipation pushed further and further back, enslaved Africans marched to Fort Frederik, the Danish fort on the western end of the island and the counterpoint to Fort Christiansvaern, and demanded that then-Governor Peter Von Scholten grant them their freedom. This event ultimately forced von Scholten to declare an end to slavery in the Danish West Indies, although there is much scholarly debate over the extent to which his longtime mistress, a free colored woman named Anna Heegaard, influenced this decision to end the barbaric practice of enslavement in these islands.

Following this successful uprising and the abolition of slavery, workers who had been formerly enslaved remained tied by annual contracts to work on plantations for pitiably small sums of money and, as a result, rebelled against the Danish once more in 1878 during the 'Fireburn' (or 'Contract Day') rebellion on October 1, in which workers burned down plantations across the island and demanded fair pay for their labor. Importantly, this uprising was led by four Black women, who are remembered as the "Queens" of the Fireburn. These women were 'Queen' Mary Thomas, 'Queen' Agnes (born Axeline Solomon), 'Queen' Mathilde (Mathilde Mc Bean) and 'Queen' Bottom Belly (Susanna A. Abrahamson).

These women, the leaders of the Fireburn which would ultimately consume half the town of Frederiksted and over 50 plantation estates on St. Croix, would be captured and tried in Denmark for their participation in and leadership of this uprising. It is these prison records, this remembrance, to which I now turn. In the colonial record, the period of Agnes-or Axeline's-presence in Denmark was carefully documented and quantified. Danish prison records list her prisoner's number and the crimes with which she was charged, as well as detail her possessions at the time of capture. In this instance, the documents in the Danish archive attempt to provide a complete rendering of this subject: "One earring, one sprained foot..." This way of knowing is detailed, but far from all-encompassing. For comparison, consider one way in which her co-conspirator, "Queen" Mary Thomas is remembered-is known-in the US Virgin Islands. While a quantitative prison record also exists for "Queen" Mary she is remembered in story and song in the Virgin Islands as both a hero and an ancestor-that is, she is included in kin networks as a predecessor in the Virgin Islands. Beyond being known as a quantifiable entity, she is remembered as a foremother. For instance, in the fourth-grade children's textbook of Virgin Islands history entitled "Clear de Road" published in 1983, Queen Mary is situated as a leader of a communal revolt-the lyrics of a song which bear her name include "don't ask me nothing at all. Just pass me the match and oil," a set of commands that posit a situation in which Queen Mary and the hearers of this song engage in a joint enterprise for Black freedom over space and time. This song is sung by schoolchildren and professional musicians alike 
across the Virgin Islands. This way of knowing, of engaging with previous generations of Virgin Islanders-figures like Queen Mary and Queen Agnes-is, I argue, a more complete way of situating these figures and engaging with Virgin Islands history.

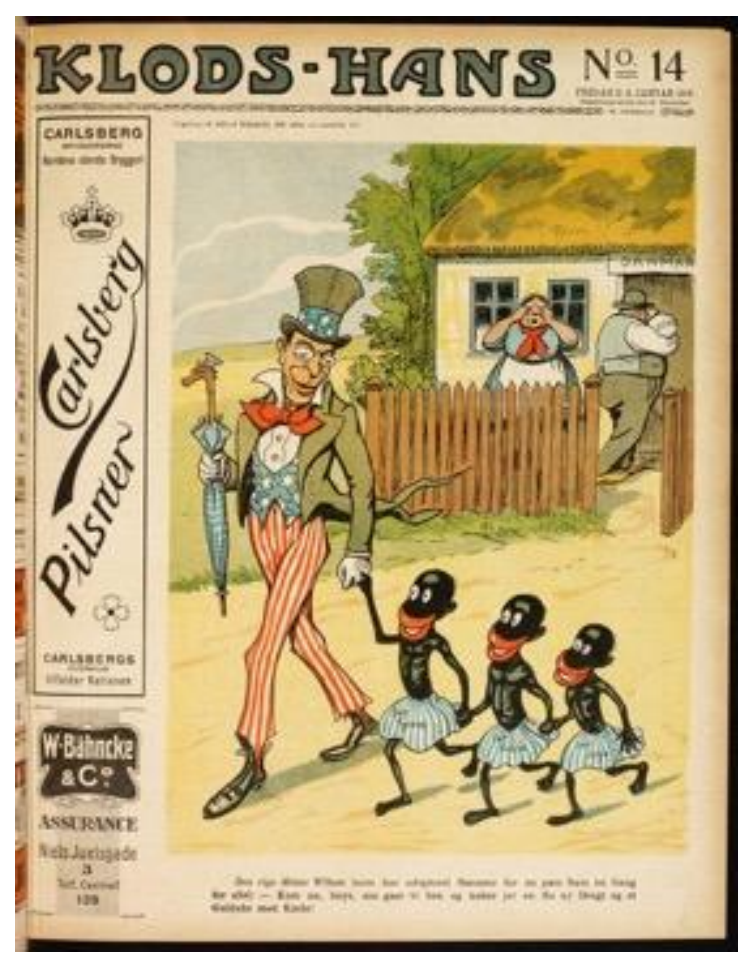

Figure 1. In this caricature from the magazine KlodsHans, President Woodrow Wilson leaves with the three small islands in the form of three black boys, while the
In engaging with Danish archives we are confronted with racist representations of Black subjects, but also-for many Virgin Islanders-with the generative possibility of encountering community members and ancestors. This is the project I am pointing toward-the possibility of situating and experiencing archival material in different contexts. That is, how different it would be if such images were not just digitized by Danish institutions and shared with those in the Virgin Islands, but housed-and, importantly, situated there? Would figures like Queen Agnes be recognized as grandmothers, great aunts, crucial parts of their community? The removal of such objects from their context-the people and places which made them possible-is an act of erasure that continues even after attempts to repair this break with gestures such as the digitization of archival material.

This is where the question of social justice becomes central: In 2017, a group of four Black women from the Virgin Islands came together to form the Virgin Islands Studies Collective (VISCO). We formed this collective as a group of Black feminists to create a space in which we could both ask and attend to questions such as the one that has been my preoccupation in this essay: What would it mean to not just include, but center, Black life in the former Danish West Indies? What would it look like if these subjects were more fully known? To this point, one of our central planned interventions is the creation of a virtual museum, where archival material that is held in Danish archives and has recently been digitized can be housed. While having digital access to this material has beenand continues to be-important, we argue both that the way in which these documents are archived are outside of the frame of reference for Virgin Islanders-and that vital context that could be provided by Virgin Islanders is currently missing. Not just, for instance, the names and social locations of photographed subjects, but also larger cultural indicators. Does, for instance, a particular style of hair or pattern of clothing hold larger significance for these Black subjects? This need to contextualize archival material in ways that are accessible to the descendants of Black inhabitants of the Danish West Indies is a central concern of the Virgin Islands Studies Collective-and should be also for those concerned with the Danish colonial presence in the Caribbean and its continuing legacy.

As the Virgin Islands Studies Collective grounds itself in Black feminist theory and practice, it is fitting to turn here to the words of the Combahee River Collective, whose landmark Black feminist statement celebrated its 40th anniversary in 2018. In 1978, the members of this group wrote: "If Black women were free [and here I suggest a nuanced definition of 'freedom' that includes the recognition of one's personhood] it would mean that everyone else would have to be free since our freedom would necessitate the destruction of all the systems of oppression." It is in this spirit that the VI Studies Collective seeks to center the lives and contributions of Black subjects in the space now called the US Virgin Islands. 


\section{I Too Am the Rebel Queen Mary \\ By Hadiya Sewer}

Queen Mary, ah where you gon' go burn?

Queen Mary, ah where you gon' go burn?

Don't ask me nothin' at all. Just give me the match and oil.

If you were to ask me, "when did you first learn about the Rebel Queen Mary?", I would be unable to answer the question. As a young Afro Caribbean woman from St. John, U.S. Virgin Islands (formerly St. Jan, Danish West Indies), I learned about our Queens-Queen Mary, Queen Agnes, Queen Mathilde, and the lesser known Queen Susanna-as I became conscious of my own existence. Therefore, I have no recollection of a time before I was aware of Queen Mary Thomas, one of the primary leaders of the 1878 Labor Riot on St. Croix. The Queens who led this Black working-class uprising, also called "Fireburn", on October $1^{\text {st }}, 1878$ are enshrined in the collective consciousness of the people of the U.S. Virgin Islands-St. Thomas, St. John, St. Croix, and Water Island-as symbols of resistance against intersecting systems of oppression. I grew up listening to my mother playfully calling out, "Queen Mary, ah where you gon' go burn?" and in time I learned to respond, "Don't ask me nothin' at all. Just give me the match and oil." These lyrics echoed throughout our lives in both private and public spaces, namely at home, at school, and at public performances. Queen Mary Thomas is arguably one of the most iconic and impactful historical figures of our Danish West Indian past. Truthfully, the person who I am today could not have come into being without Queen Mary's existence, without Fireburn's occurrence. The Rebel Queen Mary is a constitutive figure in my consciousness, perhaps, in the psyche of all Virgin Islanders to varying degrees. She reaches through history and makes indelible marks on us.

Given U.S. Virgin Islanders limited access to our archives and the coloniality of archival production, we should not take our remembrance of Queen Mary Thomas for granted. My reading of the coloniality of archival production is informed by several of the essays in Refiguring the Archive (Hamilton, 2002) - namely Achille Mbembe's The Power of the Archive and Its Limits and Ann Laura Stoler's Colonial Archives and the Arts of Governance. Mbembe and Stoler provide a reading of power and history that traces the relationship between archives and the state. Mbembe (2002, p. 23) writes, "On the one hand, there is no state without archives without its archives. On the other hand, the very existence of the archive constitutes a constant threat to the state." For Stoler, archives are not merely repositories of source material. Archives are also monuments of state power, "intricate technologies of rule in themselves (Stoler, 2002, p. 87)." Therefore, it is important to pose a set of critical questions about Queen Mary Thomas, the archive, the history of Fireburn, and our affective relationship to her memory. Namely, how do Virgin Islanders pin our discursive location in history and how is Queen Mary in particular a constitutive figure in our consciousness? How do Virgin Islanders' commemoration of Queen Mary Thomas capitulate to and/or resist the colonial and imperial drives of the state? In short, how do the thoughts and actions of a Black, Antiguan born, Danish West Indian ${ }^{\text {ii }}$ woman who lived in the $19^{\text {th }}$ century fashion the individual and collective identities and ideologies of U.S. Virgin Islanders to this day? What mythos surrounds Queen Mary and what is the relationship between the symbolic capacity of the Queen Mary icon and the truth of her personhood, which includes, but of course, is not limited to, the facts of her life?

Her prison records indicate that Queen Mary was 40 years old at the time of her imprisonment. She came to St. Croix in 1869, one-year shy of a decade before Fireburn. Mary Thomas was an unwed mother to three children. She had three documented run- ins with the law. Her convictions include: 1) Participation in, plundering and arson during the Rebellion on St Croix in 1878, 2) Theft, and 3) the mistreatment of her child. She had one ring and one pair of earrings on her person at the time of her incarceration. She is hospitalized several times between 1882 and 1884 for fever, menstruation colic, chest pains, catarrh, and pyelitis. Queen Mary, like other prisoners in the Christianhavn women's prison in Copenhagen were graded on their conduct. While in prison, she corresponded with individuals by the name of Mrs. Wilhelmine Petersen and Mr. and Mrs. Larsen. In 1887, 
Queen Mary was sent to Christiansted, St. Croix to serve the remainder of her sentence. These records reflect an objectifying, quantifying, colonial gaze. Why and how do we remember Queen Mary given Virgin Islanders' limited access to colonial archives?

My thoughts on our remembrance of Queen Mary are informed, in part, by Michel-Rolph Trouillot's (2012) Silencing the Past: Power and the Production of History. Trouillot's arguments, "Remembering is not always a process of summoning representation of what happened," and "Human beings participate in history both as actors and as narrators," challenge the notion that history is merely a composite for collective memory. Instead, he calls our attention to a non-linear notion of history that acknowledges the interconnectedness of both past and present. Trouillot's work on knowledge production and power reminds readers that history is produced in and outside of academia, with the history that is produced outside of the academy often being under theorized. The production of knowledge is also about processes of narrative creation, the development of political imaginaries, and the creation of the future. Given this understanding of history, our remembrance of the Rebel Queens reveals a great deal about who we are as U.S. Virgin Islanders-our histories, identities, episteme, and ontologies. Specifically, Queen Mary, both the person and the symbolic meaning attributed to her, represents a site of rupture in colonial ontologies and epistemologies and, therefore, we often invoke her in our challenging of hegemonic worldviews and practices.

Systems and techniques of domination-namely slavery, colonialism, imperialism, and hegemony-are racialized, gendered, sexual, and economic projects that are prefaced on the construction of a dehumanized "other". Sylvia Wynter $(1984,1995)$ notes that Western civilization articulates and imposes a series of hierarchized dichotomies to describe the social order-civilized/uncivilized, white/black, man/non-human, man/woman, rich/poor, colonizer/ colonized, Christian/non-Christian, and citizen/non-citizen. These epistemological frameworks are constrained by the binary construction of founding and liminal categories (Wynter, 1995). Founding categories are central to the discourse whereas liminal categories refer to the marginal and antithetical. Wynter also argues that the oppressive structures of our prevailing world order are rooted in dehumanizing behavior orienting narratives. Her seminal argument contends that our oppressive world structures are rooted in the overrepresentation of "Man", a specific prototype of being human in the West that attempts to eclipse "the human" (Wynter, 2003).

Queen Mary-a Black, working-class, incarcerated, colonized, unwed mother, and immigrant-is located on the intersection of multiple liminal categories. Sylvia Wynter's work poses the question can the hegemonic structuremaintaining process of juxtaposing founding and liminal categories in our discourses be transcended? Wynter does not answer this question for her interlocutors. However, Wynter (2003, p. 268) does offer the poignant argument, "One cannot 'unsettle' the coloniality of power without a re-description of the human outside of the terms of our own present descriptive statement of the human." Decoloniality requires new conceptions of the human, an epistemic break. In her time, Mary Thomas' willingness to risk her own life and freedom to set Frederiksted ablaze for a step towards racial and gendered economic justice, disrupted the efficacy of the plantation economy and the racist colonial order. Yet, "Fireburn" also shifts the imaginaries of U.S. Virgin Islanders. We are privileged to have counter-hegemonic Black heroines at the crux of our collective identity. Our commitment to the commemoration and representation of these Rebel Queens speaks to a desire for counter hegemonic behavior orienting narratives ${ }^{\mathrm{iii}}$, new descriptive statements of the human. Wynter (1970) reminds us that the decolonial project is also a humanization project. Queen Mary signifies a new humanism, one that may not even seem readily possible according to the logic of our prevailing world order, one where Black women are central to quests for freedom and humanization.

Commemorations of Queen Mary point to a new humanism in ways that often challenge the colonial order of things. For example, La Vaughn Belle and Jeannette Ehlers' I Am Queen Mary monument in Copenhagen highlights 1) the importance of Black women's artistic and intellectual contributions to this world, which include but cannot be reduced to, disruptions of colonial space and 2) the potency of Queen Mary as a radical symbol. 
The 23-foot monument, the first of a Black woman in Denmark, interrupts the silences that mask(ed) Denmark's colonial histories. Queen Mary, sitting on coral harvested by the enslaved people of the Danish West Indies, asks us to grapple with the violent traumas of our past and decide who we will be now and in the future. It seems fitting that a piece of this magnitude would also be the result of Afro Diasporic women's transnational collaboration, between Denmark and the U.S. Virgin Islands. A part of the art's genius lies, in part, in its representation of the malleability and elasticity of Queen Mary's image and legacy.

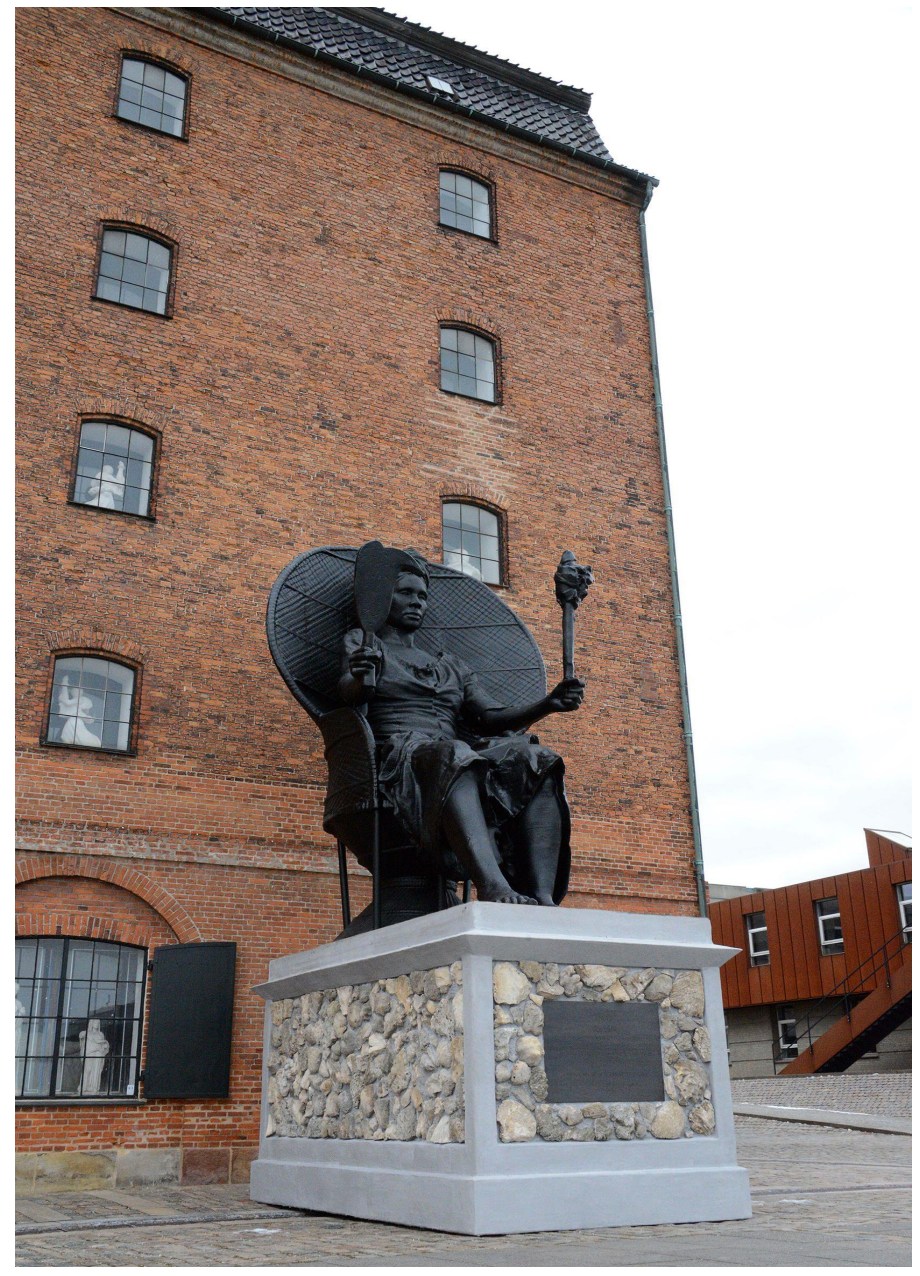

The piece was created as a hybrid of the artists bodies and many students of Africana history can quickly recognize the similarities between Queen Mary's seating arrangement and Huey P. Newton of the Black Panther's Party's historic photograph. While some Virgin Islanders critiqued the subtle, or not so subtle, play with Black bodies, genders, histories, and narratives in this monument of our Rebel Queen, there is a truthfulness in it.

Whether it be through songs, paintings, film, re-enactments, history lessons, or the I Am Queen Mary statue, we create and recreate Queen Mary Thomas in our image. We opt to embody her. Perhaps, it is through Queen Mary that we learn, or in some cases remember, how to choose our freedom, visibility, and humanity in the face of the "matrix of domination"iv. In some ways this is a cautionary history lesson. Her imprisonment, and the death of her comrades, reminds us of the risks and limitations of subversion. They made the sacrifice nonetheless. Her narrative reminds us that epistemic ruptures are never clean breaks, as Sylvia Wynter (1995) writes. Fragments of the old hegemonic ways of being and knowing persist. So, there is also a paradox in our reverence of the Rebel Queens.

Figure 2. La Vaughn Belle and Jeannette Ehlers. Photo Credit: Nick Furbo

She expands our imaginaries and our relations are still fundamentally colonial. In the midst of continuous colonial subjection, Queen Mary Thomas reflects our unrealized desires for freedom against all odds. This is why she is our Queen. We map multiple layers of (im)possibility onto her symbolic person as we try to determine who we are becoming. 


\section{Enslaved to Enthroned: a personal reflection on the rebel Queen Mathilde McBean \\ By Tiphanie Yanique}

To become a pageant queen, I had to do one thing very well. This thing was the curtsy.

I had learned the curtsy as a debutante months earlier. The VI version wasn't your run of the mill curtsy. The debutante had to keep her back straight, one foot perpendicular in front of the other, her head up, eyes forward, arms out and curved as if holding an extra large beach ball under each arm. Then the young woman performed a meticulously slow bending of the knees until one knee tapped the floor. It was best to wear a hooped princess dress of tulle and crinoline, which would poof around you, as if you were settling elegantly onto a cloud. A male escort held one hand to make sure you didn't topple over and smash your face.

Then back up, which was harder. This is where your young man had to give you a little tug to help you, because it was near impossible to get back up in heels. You had to do the curtsy without shaking, without needing your own hand to catch you. You had to do it slowly. Months later when I was in the beauty pageant, in the same dress I'd worn as a debutante, I was ready to do the curtsy on stage. But I had a problem. Another contestant before me had done the curtsy first. When it was my turn, I couldn't see the people, given the stage lights. But their teeth sucking was loud enough. As far as anyone could say, I was just copying the first girl.

Being in a pageant wasn't just a big deal for me. It was a big deal for a lot of people. In her book, Queen of the Virgins, Cynthia Oliver writes that pageants are "rehearsal for intraclass politics, the place where women of middle and upper classes have used their influence to solidify their place in local society" $(2009$, p. 4). I was the only girl competing to be queen of the school who was on scholarship. I was from Round da Field, a poor and often dangerous neighborhood. My school was Anglican, and I was Catholic. I was repping steel pan, which I performed for my talent, while other girls sang, danced or recited poetry. Pan was considered a carnival instrument, which in our society tended to mean that it was aggressive--masculine even, and certainly not sophisticated or feminine. Only one other girl in my entire school played pan--and she was running against me in the pageant. She'd chosen to sing an American R\&B ballad by Mariah Carey or Whitney Houston--something considered ladylike. That she played pan at all was something that never made it to any part of her stage persona. Pan wouldn't have been representative of queenly aesthetics, which, as far as we young contestants could tell, were American and European based ideals of queenliness.

As for my part, I wasn't representative of the elite school I went to at all. Our principal's slogan for each student was: "You are what you are because you are All Saints Cathedral School." Every student had to be crisp and coiffed even on a regular day. Whomever won the queen pageant would be "Miss All Saints" and thus the example to all other students on what All Saints was and could be. In parades, Miss All Saints would wear a sash and crown and the school's name on her chest. At minor events like a sports game, the queen would preside in regalia. At major events in the community, like meetings of the territories actual legislature, Miss All Saints would be there--crown and sash with her school's name on it. Everything the queen did would be in the school newsletter, and very often would also end up in the islands' major newspaper, too.

Vapid as we all know pageants can be, I knew I was more than just me standing up there. Yes, I'd been a debutante, and it was true that I knew (thanks to my grandmother) the difference between a grapefruit spoon and a teaspoon. But I was also the girl without a professional pageant coach; a girl who cursed, and fought in school; the girl the boys with the prestigious last names would never date. I was on a full scholarship, even though the school had no scholarship program---leading me to conclude that I may have been the only one on scholarship in the whole school. I was offering another narrative of what our school was, which made me something of a rebel. And I was on stage now trying to be the school's queen.

Which brings me to our rebel queens. In the Virgin Islands we already had another narrative of queendom - one not squarely about pageantry, but about protest. I was raised, as everyone raised in the Virgin Islands is, on the 
story of the queens of the 1878 labor revolt known as the Fireburn. Queens of that time were delegated by the workers on the plantations as people to perform religious and cultural ceremonies, go to with complaints, trust with secrets. Mathilde was the youngest of the rebel queens-not much older than I was when I ran in that pageant. She and her co-queen, Agnes, were both in their early twenties-though Mathilde may have been even younger than that. The elders, Susannah and Mary, were in their 40s. Whereas Mary was born in Antigua, Mathilde and Agnes were born and raised in the Virgin Islands-and when we talk about queendom as representing, we must think about what these women were representing.

Born and raised in St. Croix, Mathilde would have seen much of her family impacted by the meager pay for their hard work. Indeed, the elders of Mathilde's family would have been born into slavery. They would be able to clarify how much this new "free" working situation was actually akin to slavery itself. Mathilde would have been a leader in the Fireburn not just for herself, but for her whole community.

The day of the rebellion was a day off. Usually, it was even a day of revelry. This day in 1878, however, was more quiet than normal-we know now it was because there was a labor revolt afoot. In the image we have of the time, Queen Mary, the leader, looks villainous, worthy of the hard labor she and the other queens are sentenced to for life. Nothing of her personhood is in that image.

Well, nothing except the torch raised in one hand, and a machete in the other. But in reality, this was supposed to be a day of leisure. We can imagine that the four queens may have dressed as they normally would that dayin their good dancing clothes, their elaborate head ties, their rings and, of course their best gold earrings. And wouldn't this have been especially true of Mathilde and her age mate Agnes? Perhaps the machetes and torches would have been hidden away where the women could meet and gather them together. The archive does put at least three of them in the same place, where it was said they together killed two armed soldiers. When the queens picked up the torches to burn, they may have looked, well, beautiful. Mathilde was a young woman in the prime of her life. When things turned ugly, how could she not have looked like any queen leading troops into battle might?

By Mathilde's time, white upper class women on the islands had already codified white femininity as the only beauty allowed expression in polite society. Back in 1786, there had even been an ordinance established in the Virgin Islands which disallowed brown and black women from being adorned, because wearing lace and chint ${ }^{v}$, wearing hoop dresses, wearing jewelry-brought too much aesthetic attention to non-white women. The point of jewels and fancy clothes on a woman was to draw attention to her beauty; and brown-skinned women were catching too much undeserved attention for their beauty--who the hell did these brown-skinned women think they were? How dare they rival for aesthetic attention!

It's true that I wasn't thinking about Mathilde the evening that I was in that pageant. And even in thinking of her now, I have to imagine things, because the archive is spare. But she and I would not have been so different in our positionality. She was one of the black women allowed tulle and lace. She worked in the cane fields--which was a hard labor job--a masculine job. Back on stage, I knew I didn't have a chance if this whole pageant thing was only about beauty. I wasn't considered the prettiest girl, or the most refined. But when it came to that curtsy I had a rebel-girl secret: I could do the curtsy without a man to help me.

After the sucking of teeth that told me I hadn't differentiated myself enough from the previous contestant, I stepped away from my escort and walked to the front edge of the stage. I sank down slowly and carefully. I waited there at the floor, looking to my left and my right, probably appearing dramatic, but also, gathering my strength. One person shouted, "She can't get up!" I remember thinking the same. But I put my arms out for balance, and raised myself back up slowly. People started screaming. And it was the strength that I really think everyone cheered me on for. "She win!" someone shouted out. I had kept myself straight, elegant and strong as a gleaming blade. 
And then I did win. Really. Crown and sash and the whole thing. I became a queen.

The nature of pageant queendom would seem to have very little to do with the nature of rebel queendom. But $\mathrm{VI}$ oral tradition records in song and story that at least some of the rebel queens appeared in carnival processions-in fancy clothes, with elegant fans. There is no stretch between this image and the image of our modern day pageant queens-who process during our Carnival parades and often with elegant fans. Perhaps pageantry isn't so divorced from revolution. To become a plantation queen also would have meant being raised above other woman. It would have been competitive. Mathilde, called Bottom Belly in our calypsos for generations, wasn't even the original Bottom Belly--that was more likely to have been Susannah. Was there animosity between the eldest, Susannah, and the force-ripe Mathilde? How did Mathilde, so young, and also from Christiansted, become a queen of a town that wasn't her birth town, Frederiksted? The archive gives some evidence, but I still must go to my own experience of being from the wrong town, of being a young woman from the Virgin Islands, trying to represent.

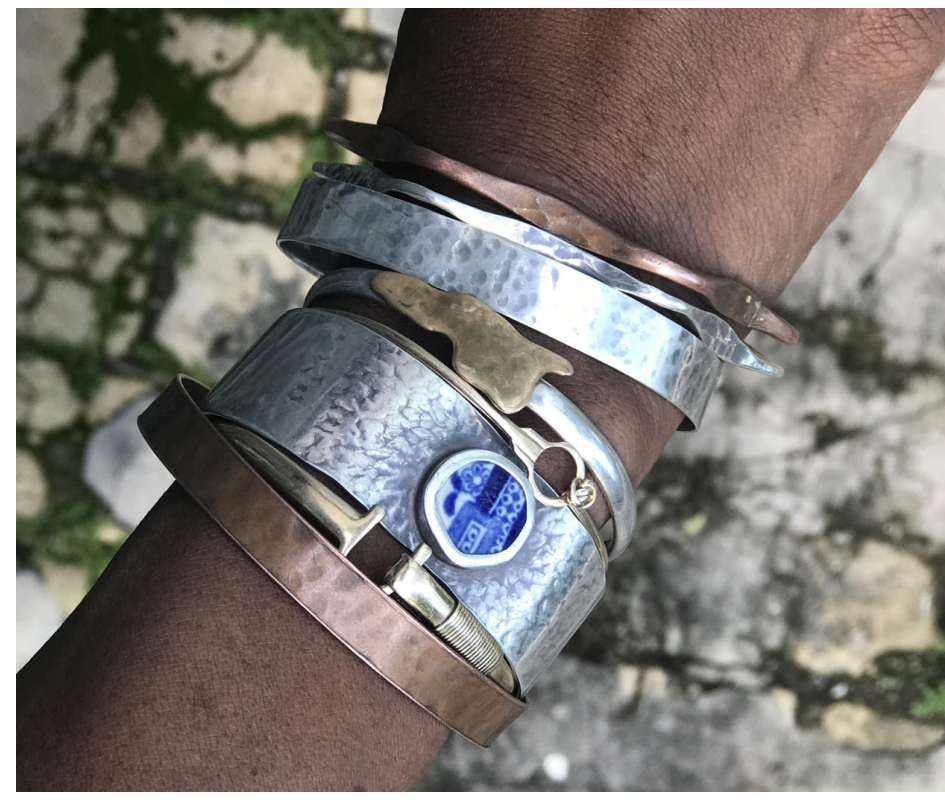

Figure 3. Wrist of a VI woman with typical and traditional VI jewelry. Photo Credit: La Vaughn Belle
I know first-hand how ugly things could get between women who wanted to represent. The girl, in fact, who had curtsied before me, had been one of my best friends, but competing against each other frayed our friendship. Many years later, another girl who had competed for the title that night, confessed that she had pretended to be our school's queen at a formal function I hadn't known about. The queendom, after all, was about representing. And to be sure, not everyone thought I was a fit representative. The women I was on stage with may have been my friends before the pageant, but that didn't mean they thought I was the right class, the right anything. Which brings me back to Mathilde-and her co-queens.

The four queens were queens of different plantations, but the connection of friendship would have been particularly meaningful for Mathilde once she and the other queens were taken from St. Croix and jailed in Denmark. Like me, Mathilde was Catholic and also a single mother to three children; marriage being perhaps too expensive or too unnecessary for her. Being unwed may have been normal, but it may have made Mathilde, the lone Catholic among the queens, an outsider in her own religious community. Still, after the Fireburn, Mathilde was incarcerated in a non-Catholic country. It must have been lonely. Denmark wouldn't have allowed her rosary beads for prayer. The archive says Mathilde had nothing but her earrings. Likely those same gold earrings she wore on the day of the Fireburn.

In the archives, however, we also see that when in jail in Denmark, Mathilde and Agnes each suffer, for the same exact days, of a headache. We readers know that faking sick has often been used as a form of rebellion by incarcerated people. Here the two women seem to be conspiring. Born around the same time on the same island, they would have been contemporaries, and yes, maybe even friends. There are Agnes and Mathilde getting together in the infirmary to talk or conspire. Or maybe just to be with a friend from home for a few days without the burden of hard labor. I am imagining their friendship as an earned thing, and coming from their commonality. 
Which brings me to something the rebel queens, and maybe all queens, have in common. We often think that the rebel queens would never have been aesthetic queens. But the archive may give us another possible narrative. In jail, all the queens had their earrings. This adornment seems important. These were women who were laborers, but still women who wanted to be treated as something treasured; who wanted to treat themselves. These women took something beautiful to prison with them. Indeed, the rebel queens wore their gold earrings while they burned the plantations down. This was a little bit of beauty even as the queens did the hard work of revolt, and later of prison life. Something akin, if I may be allowed to imagine it, to my curtsy.

We know that when pageant queens rep their schools and their islands, it is a social act. The rebel queens were not dissimilar. Our Fireburn queens remain representative of St. Croix, of the Virgin Islands. They are our royalty, with all the connotations of power, and, yes, of beauty.

\section{A Queen by Another Name: Susanna Abrahamson aka Bottom Belly \\ Or}

I Am My Own Empire: Susanna Abrahamson aka Bottom Belly

Or

Queen Susanna and the Bottomless Imaginary of a Black Queen

Or

Queen Susanna and the Bottomless Imperial Imaginations of a Black Queen

By La Vaughn Belle

My mother named me after a queen. She told me she had seen the name of a carnival queen in a newspaper in Trinidad and had liked it. I had forgotten to ask her if she had seen the name and held on to it, claiming it from then to be mine. Was I in her belly yet? Was I even a thought yet? Were there qualities about this queen she hoped I would embody? Or was it just the name, its look and its sound that drew her to place it upon me? My mother is no longer here for me to ask her these questions and it didn't occur to me until much later in life that these were questions I might have even wanted answered. Hence this compact story of how I got my queen name was something I did not always know. But what I did learn very early on growing up in the Virgin Islands, first on St. Thomas and later on St. Croix, is that our queens were different from the ones in storybooks that lived in castles. Those queens were born. Our queens are made. Whether they be queens of pageants, carnivals, labor revolts or slave rebellions, through your own fashioning, determination, your own work and imagination you could lead yourself into a realm and become the kind of queen that was impossible to dethrone and impervious to invasion. Our queen means: you are your own empire. You rule yourself, your body, your destiny and even when that wasn't entirely true due to history and circumstance, you believed it to be true, you moved as if it were true because you understood that life is the realm of fiction anyway.

Although not identified in the prison records we know through the collective memory that Susanna was the only one of the women known as the Queens of the Fireburn to have had another moniker. Monikers are so common in the Caribbean that even monikers have monikers aka home names, nicknames, dread names and street names. Sometimes they are self-inscribed, but mostly they are given to you by way of your appearance, your demeanor or some idiosyncrasy of either. If you are big-boned they call you Mega, if you have a proclivity to steal, Repo, glamorous and good-looking, Hollywood, vibezie and dreaded, One Loc, and so on. So although I don't know for sure, Susannah aka Bottom Belly quite possibly had a belly that was as big as her bottom, whose girth may likely have been seen as part of her power, part of her ability to claim and take up space. Or maybe it referred to something else. Maybe her belly was a barometer. Maybe it referred to a fearlessness that had no 
limit, no bottom, no end. Maybe this bottomlessness is what appears in the records as waywardness ${ }^{\mathrm{vi}}$ and prone to criminality, but was really her attempt at sovereignty.

Susanna was the oldest of the Queens. She was 48 years old at the time the prison records were created in 1882 which places her at the time of the 1878 Fireburn at approximately 44/45, the age I am now. She is documented to be the mother of 9 children, unmarried and with the longest rap sheet of the group. At 19 she is thieving and 23 fighting, 25 insubordinate and 26 vagrant. By 44 she graduates to plundering and arson aka the Fireburn. And if we understand her plundering and arson as a total rejection of the oppressive system that had been superimposed upon them after the abolition of slavery, what can we then understand vagrancy and theft to be in this same system? Can you thieve what was first stolen from you? Could she have the right to exist outside the plantation labor system? Did she have a right to live an unlabored life?

We see in the records that for their attempts to answer these questions Susanna along with the other Queens were sentenced first to death in 1881 . This was not unexpected. There were twelve men who when asked about their role in the revolt of the plantation system boldly and courageously confirmed their participation which resulted in their swift execution. John Adams, John Charles, James de Silva, Augustus George, Thomas Graydon, Joseph Harrison, Samuel Henry, Henry James, Robert James, John Lewis, Joseph Paris and Daniel Phillips were not venerated in song, portrayed in paintings, reenacted in sculpture or the streets. Instead they have been encased in the archives and forgotten. So too have the other men whom in their equivalence could be seen as the Kings of the Fireburn- James Emmanuel Benjamin, Joseph Bowell and Edvard Lewis. Although they, like the women, were also tried and sent to prison in Denmark, their existence in the archives did not guarantee ascendance into the realm of the remembered. To do that one had to graduate into mythology, become a part of the memory of many, the memory of we. There is a distillation that happens in this process however. Dates, names, places and other particulars become rinsed away and what remains are symbols, open and ample for projections and interpretations. So Susanna Abrahamson, Axeline Solomon, Mary Thomas, Mathilde McBean and Rebecca Frederik, noted together as the "Black Amazons"vii, in this process of mythologizing, five queens become four and four become a trinity, a memory of we. Likewise when the Danish government mints a coin in 1907 to highlight their three island colonies we project our memory of we onto it. This coin that depicts three nearly naked Greek antiquity styled women, each holding an item to symbolize the essence of the colonial value of each island, our mythology and imaginary transformed it. We redirected the current of their currency and superimposed our Fireburn queens because our queens are fashioned from the belly of our own bottomless imaginations.

This would not be the first time that we could transform the meaning of what black women's bodies could be. By the measures of the colonial system black women's bodies meant two things: laborers and breeders of more laborers. So there is an irony when we look at the prison records and see that their punishment for the Fireburn after their death sentences were commuted is hard labor. These women were cane cutters, their lives spent working in the times of day when the sun burnishes, in labor that is oppressively monotonous and physically compromising. In effect, their lives had already been full of hard labor. And so one wonders what kind of labor was harder than cane cutting? The foundations of the buildings and towns had long since been built by previous hard laborers, the enslaved that were taken from the western coast of Africa who were forced to harvest coral stones from the sea. Their labor involved standing naked in the ocean at low tide, but sometimes dangerously not, and with certain sudden variations between the blistering sun and the biting cold breeze whipping off the sea top. So in effect a sentence of hard labor seems like a redundancy. But the Queens had transformed the meaning of their bodies into something else, their own empire. For this crime, they were not executed, perhaps fearing martyrdom. Instead they among many others were hidden away in prison for years after the Fireburn, signaling that the prison records can also be seen as a forensic record. We can see them as evidence of why the British Consul intervened, worried for their own immigrated subjects, like Queen Mary from the British ruled Antigua (Tyson, 1984). They complained that the Danish crown was violating recognized human rights and that you could not simply hold people indefinitely without a trial. But maybe what they most feared was that the 


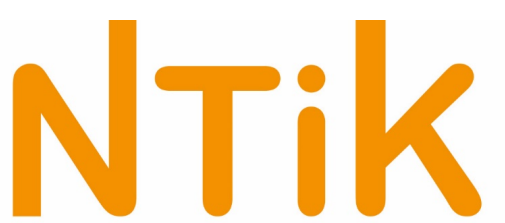

Nordisk Tidsskrift for Informationsvidenskab og Kulturformidling

injustice was too obvious, too open and uncloaked in law. Indeed what they probably most feared is what all colonialists feared - rebelirium. From Queen Breffru and the Akwamu people who in 1733 chose a fighting death instead of slavery in St. John to the multi-nationed people in Haiti who waged war on the French for their freedom, what colonialists most feared is not just rebellion, but how it inspires more rebellion, leaping like fire to other islands, consuming its inhabitants like a righteous plague. So the Danes hoped that by quarantining the Queens, first for years in the Fort in Frederiksted and even for some more years across the Atlantic in Copenhagen that they could contain what the Queens inspired. They could not. The transmutation had already begun and the Queens encoded embers into our memory of we.

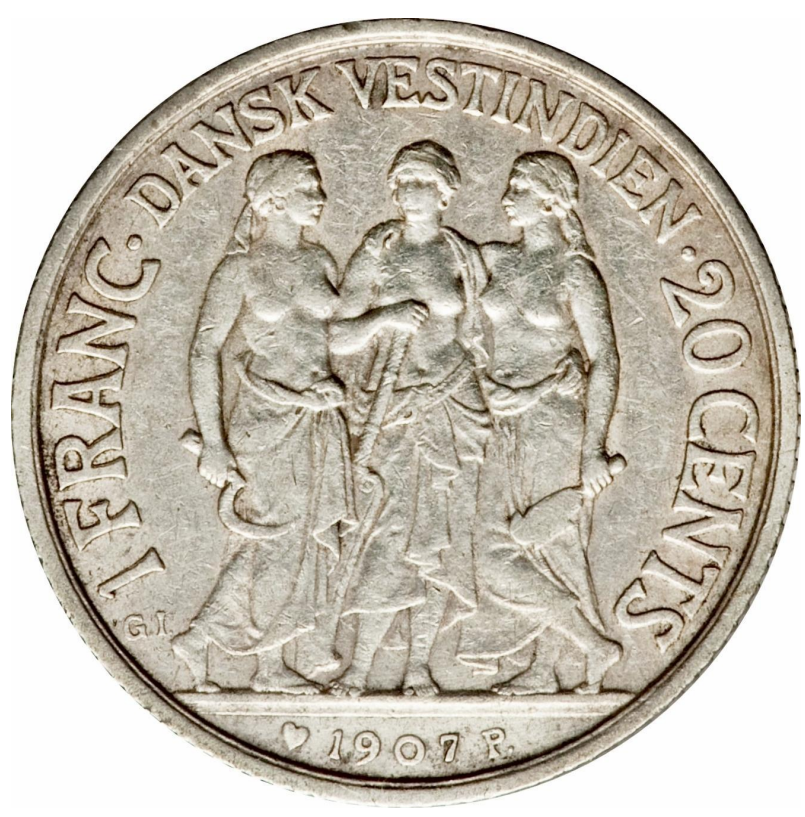

Figure 4. Danish West Indian coin minted in 1907.

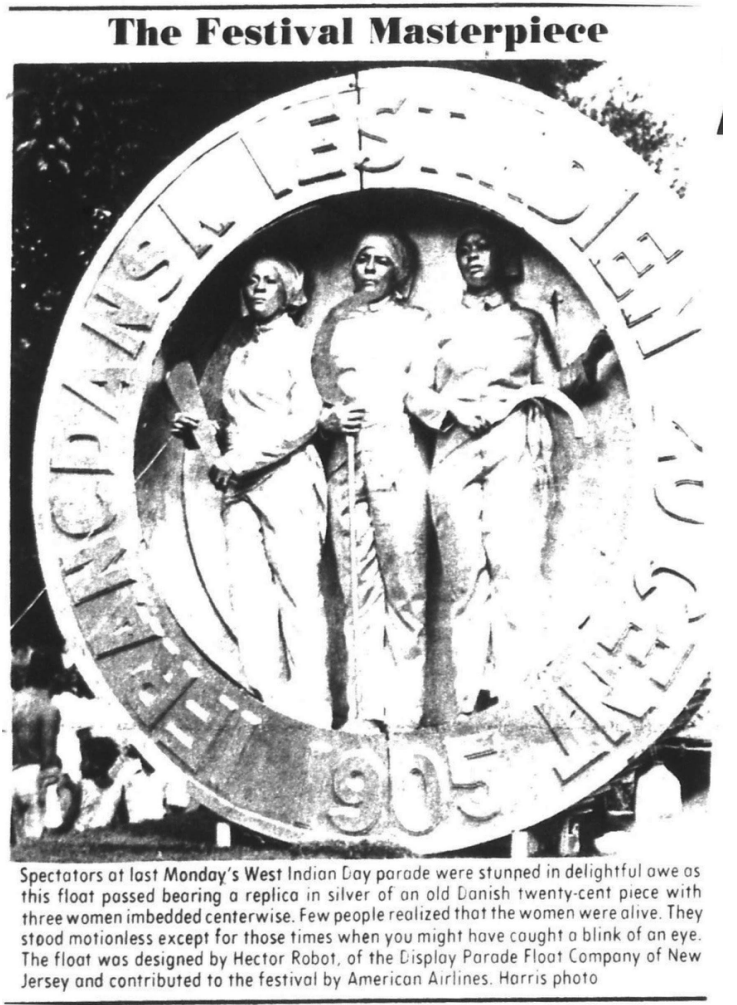

Figure 5. Taken from the Amsterdam News in 1973 of a float in the West Indian Day parade in Brooklyn.

What we can learn from these women who emerge from the unremembered is the possibility and promise in their declaration of sovereignty. Bodies destined for hard labor, yet forced to sit idle in prison demonstrate that their value transcended the service of the colonial system. We see how they stand or perhaps more radically sit, as does the figure in the monument I Am Queen Mary, as a symbol in direct opposition to the colonial empire. She is a sitting Queen, a black woman barefoot and in workers clothes, with workers tools but upon her command they become liberatory. She sits unlabored, unfettered announcing I Am Queen Mary, I Am Queen Agnes, I Am Queen Mathilde and I Am Queen Susanna- I am my own empire. This declaration reverberates across time and space and becomes a guidepost to ask new questions of the archives, questions that may not have even occurred to us yet that we want answered. 


\begin{abstract}
Virgin Islands Studies Collective (VISCO)
La Vaughn Belle makes visible the unremembered. She is a visual artist working in a variety of disciplines that include: video, performance, painting, installation and public intervention projects. She explores the material culture of coloniality and her art presents countervisualities and narratives. She has exhibited in the Caribbean, the USA and Europe in institutions such as the Museo del Barrio (NY), Casa de las Americas (Cuba), the Museum of the African Diaspora (CA) and Christiansborg Palace (DK). Her work has been featured in a wide range of media including: The NY Times, Politiken, VICE, The Guardian, Time magazine, Caribbean Beat, the BBC and Le Monde. She is the co-creator of I Am Queen Mary, the artist-led groundbreaking monument that confronted the Danish colonial amnesia while commemorating the legacies of resistance of the African people who were brought to the former Danish West Indies. She holds an MFA from the Instituto Superior de Arte in Havana, Cuba, an MA and a $B A$ from Columbia University in NY. Her studio is based in the Virgin Islands.
\end{abstract}

Tami Navarro is the Associate Director of the Barnard Center for Research on Women (BCRW) and Editor of the journal Scholar and Feminist Online. She holds a Ph.D. in Cultural Anthropology from Duke University, and has held positions at Rutgers University, Columbia University, and Wesleyan University. Her research has been supported by the Mellon Foundation, the Wenner-Gren Foundation, the Social Science Research Council, the American Anthropological Association, and the Ford Foundation. Tami Navarro has published work in Cultural Anthropology, American Anthropologist, Transforming Anthropology, Small Axe Salon, The Caribbean Writer, Social Text, and The Global South. She serves on the Board of the St. Croix Foundation and is a member of the Editorial Board for the journal Small Axe: A Caribbean Journal of Criticism. She is currently completing a manuscript entitled Virgin Capital: Neoliberal Development in the US Virgin Islands, to be published by the State University of New York Press.

Hadiya Sewer is a Visiting Scholar in the Center for the Study of Slavery and Justice at Brown University. She earned her B.A. in Sociology from Spelman College and her M.A. and Ph.D. in Africana Studies from Brown. Her work looks at Africana philosophy, Caribbean political theory, feminist theory, and environmental justice in the Caribbean. She is also the President and Co-Founder of St. JanCo: the St. John Heritage Collective, a land rights and cultural heritage preservation non-profit in St. John, U.S. Virgin Islands and Vice President of Program Development and Outreach at the Virgin Islands Youth Advocacy Coalition.

Tiphanie Yanique is a novelist, poet and essayist from the Virgin Islands. She is the author of Land of Love and Drowning, which the First Novel Prize for a best first book of fiction published in the US, and Wife, which won the UK prize for a best first of poems published in the UK. Tiphanie is a professor of creative writing and literature at Emory University in Atlanta, Georgia. 


\section{NTik \\ Nordisk Tidsskrift for Informationsvidenskab og Kulturformidling}

\section{References}

Abel, S., Tyson, G., \& Palsson, G. (2019). From Enslavement to Emancipation: Naming Practicing in the Danish West Indies. Comparative Studies in Society and History, 61(2), 332-365.

Bastian, J.A. (2001). A Question of Custody: The Colonial Archives of the United States Virgin Islands. The American Archivist, 64 (1), 96-114. doi: 10.17723/aarc.64.1.h6k872252u2gr377

Bastian, J. A. (2003). Owning Memory: How a Caribbean Community Lost Its Archives and Found Its History. Westport, CT: Libraries Unlimited.

Collins, P. H. (1990). Black feminist thought: knowledge, consciousness, and the politics of empowerment. Boston: Unwin Hyman.

Dookhkan, I. (1994). A History of the Virgin Islands of the United States. Kingston: University Press of the West Indies.

Hall, Neville A.T. (1992). Slave Society in the Danish West Indies: St. Thomas, St. John, and St. Croix. Baltimore: Johns Hopkins University Press.

Hamilton, C. (Ed.). (2002). Refiguring the archive. Dordrecht; Boston: Kluwer Academic.

Hartman, S. (2019). Wayward Lives, Beautiful Experiments: Intimate Histories of Social Upheaval. New York: W. W. Norton \& Company.

Oliver, C. M. (2009). Queen of the Virgins: Pageantry and Black Womanhood in the Caribbean. Jackson: University Press of Mississippi.

Ruprecht, A. \& Taiana C. (Eds.), (1995). Reordering of Culture: Latin America, the Caribbean and Canada in the Hood (pp. 17-41). Ottawa: Carleton University Press.

Rezende, E. (1998). Cultural Identity of the Free Colored in Chirstiansted, St. Croix, Danish West Indies, 18001848. Unpublished doctoral dissertation. Retrieved from UMI Dissertation Services (9834146).

Thomas, G. (2006). PROUD FLESH Inter/Views: Sylvia Wynter. ProudFlesh: New Afrikan Journal of Culture, Politics and Consciousness, 0(4). Available at:

https://www.africaknowledgeproject.org/index.php/proudflesh/article/view/202

Tyson, G.F. (1984). Annotated Register of Consular Correspondence Concerning the Origins, Events and Aftermath of the St. Croix Labor Insurrection of 1878. Found in the British Foreign Office Papers at the Public Record Office, Kew, England, pp. 15-16. Submitted to the Bureau of Libraries, Museums and Archaeological Services, Department of Conservation and Cultural Affairs, Government of the Virgin Islands.

Wynter, S. (1970). Jonkonnu in Jamaica. Jamaica Journal, 4(2), 34.

Wynter, S. (1984). The Ceremony Must be Found: After Humanism. Boundary 2 (12/13), 19-70. https://doi.org/10.2307/302808

Wynter, S. (1995a). 1492: A New World View. In V. L. Hyatt \& R. M. Nettleford (Eds.). Race, discourse, and the origin of the Americas: a new world view (pp. 5-57). Washington: Smithsonian Institution Press. 
Wynter, S. (1995b). The Pope Must Have Been Drunk, the King of Castile a Madman: Culture as Actuality and the Caribbean Rethinking of Modernity. In Ruprecht, A. \& Taiana, C. (Eds.), Reordering of Culture: Latin America, the Caribbean and Canada in the Hood (pp. 17-41). Ottawa: Carleton University Press.

Wynter, S. (2003). Unsettling the Coloniality of Being/Power/Truth/Freedom: Towards the Human, After Man, Its Overrepresentation-An Argument. CR: The New Centennial Review, 3(3), 257-337.

\footnotetext{
i This image is not part of the penal records of the Queens of the Fireburn, but instead appears in a print publication held in the Danish National Archives. I include this image in order to demonstrate the troubling representations of Black subjects both in archival records and in Danish print culture more generally.

ii I do not know whether or not Queen Mary Thomas would have identified as Danish West Indian.

Here, I use the term Danish West Indian to highlight her positionality as a Black colonized subject who was living and working in the Danish West Indies at the time of the revolt and her subsequent arrest.

iii In a 2006 interview with Greg Thomas, Sylvia Wynter spoke at length about Michel Foucault's conception of truth and "behavior orienting schemas". In Wynter's work, narratives, specifically conceptions of the human, condition us towards certain behaviors and (im)possibilities. Decolonization, therefore, requires new ideas of what it means to be human that might orient humans towards liberation rather than operating in the interest of "Man", the descriptive statement of the human that Wynter often theorizes.

iv See Patricia Hill Collins' (1990) pivotal text, "Black Feminist Thought: Knowledge, Consciousness, and the Politics of Empowerment" for a detailed explanation of the "matrix of domination", a term that describes the interconnected nature of race, gender, class and positions of marginalization and/or privilege.

$\checkmark$ The reference to the restrictions placed on the dress of the free colored women is from Elizabeth Rezende's unpublished PhD dissertation entitled, Cultural Identity of the Free Colored In Christiansted, St. Croix, Danish West Indies, 1800-1848, 1998. vi I use this word wayward in the same manner in which Saidiya Hartman uses it in her book, Wayward Lives, Beautiful Experiments (2019).

vii This expression of the women as Black Amazons comes from Issac Dookhan's History of the Virgin Islands of the United States (1994, p. 231). He lists all five women in this description. There is no prison record for Rebecca Frederik as she was not sent to Denmark.
} 